\title{
A cohort study of the associations between udder conformation, milk somatic cell count, and lamb weight in suckler ewes
}

\author{
S. J. Huntley, ${ }^{\star}$ S. Cooper, ${ }^{\star}$ A. J. Bradley, †¥ and L. E. Green ${ }^{\star 1}$ \\ *School of Life Sciences, University of Warwick, Coventry, CV4 7AL, United Kingdom \\ †Quality Milk Management Services Ltd., Unit 1, Lodge Hill Industrial Park, Station Rd, Westbury-sub-Mendip, Wells, Somerset, BA5 1EY, \\ United Kingdom \\ ¥School of Veterinary Medicine and Science, University of Nottingham, Sutton Bonington Campus, Sutton Bonington, Leicestershire LE12 5RD, \\ United Kingdom
}

\begin{abstract}
A cohort study of 67 suckler ewes from 1 farm was carried out from January to May 2010 to investigate associations between udder conformation, udder half milk somatic cell count (SCC), and lamb weight. Ewes and lambs were observed at lambing. Ewe health and teat condition and lamb health and weight were recorded on 4 to 5 further occasions at 14-d intervals. At each observation, a milk sample was collected from each udder half for somatic cell counting. Two weeks after lambing, ewe udder conformation and teat placement were scored. Low lamb weight was associated with ewe SCC $>400,000$ cells $/ \mathrm{mL}(-0.73 \mathrm{~kg})$, a new teat lesion $14 \mathrm{~d}$ previously $(-0.91 \mathrm{~kg})$, suboptimal teat position $(-1.38$ $\mathrm{kg}$ ), rearing in a multiple litter $(-1.45 \mathrm{~kg})$, presence of diarrhea at the examination $(-1.19 \mathrm{~kg})$, and rearing by a 9 -yr-old ewe compared with a 6 -yr-old ewe $(-2.36$ $\mathrm{kg}$ ). High lamb weight was associated with increasing lamb age $(0.21 \mathrm{~kg} / \mathrm{d})$, increasing birth weight $(1.65 \mathrm{~kg} /$ $\mathrm{kg}$ at birth), and increasing number of days the ewe was given supplementary feed before lambing $(0.06 \mathrm{~kg} / \mathrm{d})$. High udder half SCC was associated with pendulous udders (9.6\% increase in SCC/cm of drop) and greater total cross-sectional area of the teats $(7.2 \%$ increase of $\left.\mathrm{SCC} / \mathrm{cm}^{2}\right)$. Low SCC were associated with a heavier mean litter weight $(6.7 \%$ decrease in $\mathrm{SCC} / \mathrm{kg})$. Linear, quadratic, and cubic terms for days in lactation were also significant. We conclude that poor udder and teat conformation are associated with high levels of intramammary infection, as indicated by increased SCC and that both physical attributes of the udder and SCC are linked to lamb growth, suggesting that selection of suckler ewes with better udder and teat conformation would reduce intramammary infection and increase lamb growth rate.
\end{abstract}

Received January 23, 2012.

Accepted May 8, 2012.

${ }^{1}$ Corresponding author: laura.green@warwick.ac.uk
Key words: suckler ewe, udder conformation, milk somatic cell count, lamb weight

\section{INTRODUCTION}

In dairy cattle, strong evidence exists that poor udder conformation is associated with raised SCC and an increased incidence of clinical mastitis (reviewed by Seykora and McDaniel, 1985). In dairy sheep, a linear appraisal of udder traits has been developed (de la Fuente et al., 1996; Marie-Etancelin et al., 2005; Casu et al., 2006). Casu et al. (2010) studied a flock of 900 pedigree ewes with historical data and known family relationships and detected a genetic correlation between udder conformation and mastitis and SCC with a heritability of 0.4. Currently, some European dairy sheep breeds include udder traits in their breeding programs, mainly with the aim of improving machine milking ability (Marie-Etancelin et al., 2005; Casu et al., 2006; Casu et al., 2010) but to date no work has been done on the role of udder conformation in IMI and lamb growth in suckler sheep.

Mastitis in sheep causes economic losses from costs of treatment, ewe replacements, and reduced milk production (Albenzio et al., 2002). In suckler sheep, reduction in milk yield reduces lamb growth rate: lambs reared by ewes experimentally infected with Staphylococcus simulans to induce subclinical infection had significantly lower growth rates to $52 \mathrm{~d}$ of age than lambs reared by unchallenged ewes (Fthenakis and Jones, 1990). In observational studies, clinical mastitis (Larsgard and Vaabenoe, 1993) and subclinical mastitis (either defined by presence of bacteria or positive CMT) have been associated with reduced growth rate of lambs (Moroni et al., 2007; Arsenault et al., 2008) although supplementary feed to lambs negated this association (Keisler et al., 1992), suggesting that these IMI reduce milk production.

To date, no study has been done on the associations between udder conformation and IMI and their effect 
on lamb weight in suckler ewes. Therefore, the aims of the current study were to investigate the relationships between udder conformation, SCC, and lamb weight in a cohort study of suckler ewes.

\section{MATERIALS AND METHODS}

\section{Study Farm and Ewe Selection}

A farm in Shropshire, United Kingdom, was convenience selected on willingness to participate, management of ewes in separate age groups, and handling facilities that enabled longitudinal observation of ewes and lambs. Seventy-eight ewes were enrolled into the study in December 2009: the study group comprised twenty 2-yr-old Suffolk mules, twenty 6-yr-old Suffolk mules, and thirty-eight 9-yr-old North Country mules.

\section{Collection of Ewe and Lamb Data}

In February 2010, 1 mo before lambing was due to start, ewes selected for study were examined and their ear tag numbers and BCS (Defra PB1875, undated) were recorded. Within 12 to $72 \mathrm{~h}$ of lambing, each ewe and litter was examined while still in an individual lambing pen. Each lamb was identified with an ear tag and all clinical abnormalities were recorded. Lambs were weighed using an International Organization for Standardization (ISO, 2008) assured hanging scale with 0.1-kg calibrations (Salter 235-6S; Salter Brecknell, Smethwick, West Midlands, UK) and their sex and litter size recorded. The BCS of each ewe was recorded. While the ewe was in pelvic recumbency, the udder was examined and all visible and palpable abnormalities including scars on the udder and teats were recorded. Teat lesion type, depth, position, and location were recorded and later classified as traumatic or nontraumatic. Traumatic teat lesions included bite wounds, tears and chapping. Nontraumatic lesions included proliferative skin lesions, warts, and pustules. A milk sample was collected from each udder half.

After lambing, ewes were managed in 4 groups, categorized by age and litter size. The groups were 2 - and 6 -yr-old Suffolk mules with single lambs, 2- and 6-yrold Suffolk mules with multiple lambs, 9-yr-old North Country mules with single lambs, and 9-yr-old North Country mules with multiple lambs. Ewes and lambs were examined every $14 \mathrm{~d}$ from lambing until lambs were 8 to 10 wk old. Each group was brought in from the fields to a sheltered handling facility when examined. At each examination, lambs were weighed in a calibrated weigh crate and ewes were cast in pelvic recumbency in a cradle. Ewes and lambs were examined and milk samples collected. At the second examination only, detailed measurements of the udder were made and the udder conformation was scored using a 9-point scoring system developed by Casu et al. (2006) with the ewe standing and in pelvic recumbency. In addition, the length and width of the teat were measured.

Milk samples for somatic cell counting were diluted with PBS to a volume of $20 \mathrm{~mL}$ at the University of Warwick (Coventry, UK) to facilitate automated somatic cell counting. These were kept chilled and transported within 1 wk of collection to an external laboratory (QMMS Ltd., Somerset, UK) for analysis using an automated combined spectrometer and flow cytometer [Delta CombiScope FTIR (Delta Instruments B.V., Drachten, the Netherlands)]. The results from somatic cell counting were corrected according to the dilutions used.

\section{Data Storage and Analysis}

A database was constructed in Microsoft Access 2007 (Microsoft Corp., Redmond, WA) into which observation date, ewe identification, BCS, SCC, udder conformation scores, and measurements and abnormalities of the udder, teat, and milk were stored. From the width of the teat measurement the total teat cross-sectional area was calculated assuming each teat was circular in cross section, with the teat width being the diameter (d) of the circle, and so the cross-sectional area of each teat was $0.5\left(\pi \mathrm{d}^{2}\right)$. This was summed to give the total cross-sectional area of the teats. A second linked sheet was used to store lamb identification, litter size, lamb weight, and whether lambs were thin, had diarrhea, or had scabs around their muzzle.

Descriptive analysis was performed in Stata 10 (StataCorp LP, College Station, TX). The SCC data were common logarithm $\left(\log _{10}\right)$ transformed and the normality of both outcome variables was assessed. Strata were merged where adjacent categories had less than 6 observations. Explanatory variables observed repeatedly were plotted over time categorized by ewe age and litter size. The logarithm of SCC was categorized into quintiles to investigate the linearity between SCC and lamb weight.

Two 3-level multivariable linear regression models were constructed in MLwiN 2.11 (Rasbash et al., 2009): the first with lamb weight $(\mathrm{kg})$ as the continuous outcome variable with ewe, lamb, and observation as random effects levels 3,2 , and 1 ; and the second with the common logarithm $\left(\log _{10}\right)$ of SCC (cells/mL) as the continuous outcome variable with ewe, udder half, and observation as random effects levels 3, 2, and 1. Each model took the form 


$$
\mathrm{y}_{i j k}=\beta_{0}+\boldsymbol{\beta} \mathbf{x}_{k}+\boldsymbol{\beta} \mathbf{x}_{j k}+\boldsymbol{\beta} \mathbf{x}_{i j k}+\mathrm{v}_{k}+\mathrm{u}_{j k}+\mathrm{e}_{i j k},
$$

where $\mathrm{y}_{i j k}$ is the continuous outcome variable, $\beta_{0}$ is the intercept,and $\beta \mathbf{x}$ is a series of vectors of fixed effects that vary at $k, j k$, and $i j k$, with variance estimates at $\mathrm{v}_{k}, \mathrm{u}_{j k}$, and $\mathrm{e}_{i j k}$. The independent variables were tested in the model using a manual forward stepwise selection process. Significance was set at 0.05. Where similar and highly correlated explanatory variables were tested and significant in the multivariable model, the variable that most reduced the log-likelihood per degree of freedom was retained.

\section{RESULTS}

From the 78 ewes enrolled, 73 lambed over a period of $49 \mathrm{~d}$. Sixty-seven ewes that had at least 1 lamb that survived for a minimum of 3 observations and for which SCC results were available for at least 3 occasions from at least 1 udder half were included in the analysis. Four ewes were lost to follow up due to death, including 1 ewe with acute clinical mastitis after lambing. A further 2 ewes were omitted from the analysis due to insufficient SCC or lamb weights. One ewe developed acute clinical mastitis $45 \mathrm{~d}$ after lambing; data from this ewe and her lambs were included in the analysis until $\mathrm{d} 45$. Of the 67 ewes that were included in the analysis, 36 reared 1 lamb, 31 reared twins and 1 reared triplets; 2 ewes had 1 foster lamb each. One hundred and one lambs were followed; twins and triplets were grouped as multiples. Fifty-nine lambs were male and 42 female, 16 lambs had scabby skin lesions on their muzzles, 25 had diarrhea, and 29 were visibly thin on at least 1 occasion. Forty-one ewes had at least 1 teat lesion. Younger ewes had a higher BCS than older ewes and ewes rearing 1 lamb had a higher BCS than ewes rearing multiples. Summary statistics are presented in Tables 1 and 2 .
Five hundred and ninety-two observations were made of 101 lambs between birth and 10 wk of age. At the first observation of lambs, the mean age was $1.6 \mathrm{~d}$ and mean weight was $5.3 \mathrm{~kg}$. Five hundred and sixty-eight SCC measurements were made on 67 ewes: the common logarithm $\left(\log _{10}\right)$ of SCC ranged from 4.45 to 7.65 with a mean $\log _{10}$ SCC of 5.45 and arithmetic mean SCC of 281,000 cells $/ \mathrm{mL}$. The mean common logarithm $\left(\log _{10}\right)$ of SCC was significantly higher $(P<0.05)$ in the first week after lambing compared with subsequent weeks, with a general pattern of decreasing SCC in the first 4 wk of lactation, followed by a trend of gradual increase 5 to 10 wk after lambing.

A list of all variables assessed in the univariable analysis of lamb weight $(\mathrm{kg})$ that were not in the final multivariable model is presented in Table 3. The common logarithm of SCC in left and right udder halves was highly correlated $(\mathrm{r}=0.87)$. Ewe age was positively correlated with breed $(\mathrm{r}=0.82)$ and negatively correlated with BCS $(\mathrm{r}=-0.62)$; BCS and breed were negatively correlated $(\mathrm{r}=-0.64)$.

The peak incidence of traumatic teat lesions occurred 3 to 4 wk after lambing (Cooper, 2011), the incidence then decreased gradually until 9 to 10 wk after lambing. The incidence of nontraumatic lesions gradually increased until wk 9 to 10 after lambing.

\section{Multivariable Analyses of Lamb Weight}

Lower lamb weight (Table 4) at an examination was associated $(P<0.05)$ with ewe mean SCC $>400,000$ cells $/ \mathrm{mL}(-0.73 \mathrm{~kg})$, new teat lesion $14 \mathrm{~d}$ previously $(-0.91 \mathrm{~kg})$, suboptimal teat position $(-1.38 \mathrm{~kg})$, rearing in a multiple litter $(-1.45 \mathrm{~kg})$, presence of diarrhea at the examination $(-1.19 \mathrm{~kg})$, and rearing by a 9 -yr-old ewe compared with a 6 -yr-old ewe $(-2.36 \mathrm{~kg})$. Higher lamb weight was associated $(P<0.05)$ with increasing

Table 1. Summary statistics for continuous explanatory variables

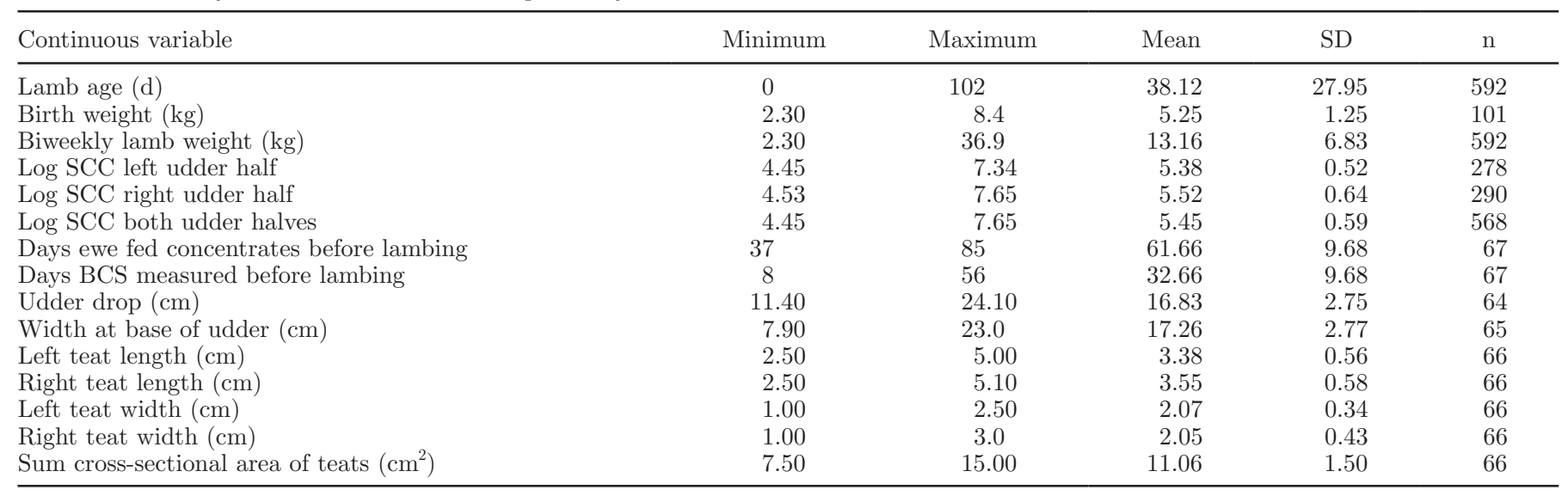


Table 2. Summary statistics for categorical explanatory variables

\begin{tabular}{|c|c|c|c|}
\hline Categorical variable & $\mathrm{n}$ & Denominator & $\begin{array}{c}\% \text { of } \\
\text { observations }\end{array}$ \\
\hline \multicolumn{4}{|l|}{ Ewe age (at lambing, yr) } \\
\hline 2 & 19 & 67 & 28.36 \\
\hline 6 & 19 & 67 & 28.36 \\
\hline 9 & 29 & 67 & 43.28 \\
\hline \multicolumn{4}{|l|}{ Litter size } \\
\hline Single & 35 & 67 & 52.24 \\
\hline Multiple & 32 & 67 & 46.42 \\
\hline \multicolumn{4}{|l|}{ Teat placement score } \\
\hline 1 to 3 (most medial) & 12 & 64 & 18.75 \\
\hline 4 & 14 & 64 & 21.88 \\
\hline 5 & 13 & 64 & 20.31 \\
\hline 6 & 12 & 64 & 18.75 \\
\hline 7 to 9 (most lateral) & 13 & 64 & 20.31 \\
\hline \multicolumn{4}{|l|}{ Udder separation (score) } \\
\hline 1 (minimum separation) & 22 & 64 & 34.38 \\
\hline 2 & 20 & 64 & 31.25 \\
\hline 3 & 14 & 64 & 21.88 \\
\hline 4 to 9 (maximum separation) & 8 & 64 & 12.50 \\
\hline \multicolumn{4}{|l|}{ Udder drop score } \\
\hline 1 (greatest drop) to 5 & 17 & 65 & 26.15 \\
\hline 6 & 24 & 65 & 36.92 \\
\hline 7 to 9 (least drop) & 24 & 65 & 36.92 \\
\hline \multicolumn{4}{|l|}{ Wool on udder } \\
\hline No & 53 & 66 & 80.3 \\
\hline Yes & 13 & 66 & 19.70 \\
\hline Udder contaminated with feces or mud at examination & 29 & 401 & 6.25 \\
\hline Clean & 30 & 65 & 46.18 \\
\hline Moderately dirty & 17 & 65 & 26.15 \\
\hline Very dirty & 18 & 65 & 27.69 \\
\hline \multicolumn{4}{|l|}{ Water availability at lambing } \\
\hline Unrestricted & 20 & 65 & 30.77 \\
\hline Restricted & 27 & 65 & 41.54 \\
\hline No water available & 18 & 65 & 27.69 \\
\hline \multicolumn{4}{|l|}{ BCS before lambing (4 categories) } \\
\hline 2 or less & 8 & 67 & 11.94 \\
\hline 2.5 & 24 & 67 & 35.82 \\
\hline 3 & 20 & 67 & 29.85 \\
\hline 3.5 or more & 15 & 67 & 22.39 \\
\hline \multicolumn{4}{|l|}{ BCS at biweekly observation } \\
\hline 1.5 or less & 24 & 401 & 0.06 \\
\hline 2 & 70 & 401 & 0.17 \\
\hline 2.5 & 97 & 401 & 0.24 \\
\hline 3 & 120 & 401 & 0.30 \\
\hline 3.5 & 56 & 401 & 0.14 \\
\hline 3.5 or more & 34 & 401 & 0.08 \\
\hline Ewe had teat lesion on at least 1 teat at any point in study & 49 & 67 & 73.13 \\
\hline Teat had lesion at any point in study & 87 & 125 & 69.60 \\
\hline Teat had traumatic teat lesion at any point in study & 67 & 125 & 53.60 \\
\hline Teat had a nontraumatic lesion at any point in study & 55 & 125 & 44.00 \\
\hline Traumatic lesion on either teat at examination & 87 & 566 & 15.37 \\
\hline Nontraumatic lesion on either teat at examination & 51 & 566 & 9.01 \\
\hline Lesion at or near teat orifice at examination & 163 & 568 & 28.70 \\
\hline Pustule or papule on teat at examination & 31 & 568 & 5.46 \\
\hline Lamb had diarrhea & 39 & 591 & 6.60 \\
\hline Lamb had suspected orf & 19 & 592 & 3.21 \\
\hline Lamb visibly or palpably thin & 33 & 591 & 5.58 \\
\hline
\end{tabular}

lamb age $(0.21 \mathrm{~kg} / \mathrm{d})$, increasing birth weight $(1.65 \mathrm{~kg} /$ $\mathrm{kg}$ ) and increasing number of days the ewe was given supplementary feed before lambing $(0.06 \mathrm{~kg} / \mathrm{d})$. The model fit was good (data not shown).

\section{Multivariable Analysis of the Logarithm of SCC}

A list of all variables assessed in the univariable analysis of common logarithm $\left(\log _{10}\right)$ of SCC that were not 
Table 3. Univariable analysis of variables associated with lamb weight not in the final mixed effects model (Table 4) for 101 lambs from 67 ewes in 1 farm

\begin{tabular}{|c|c|c|c|}
\hline \multirow[b]{2}{*}{ Variable } & \multirow[b]{2}{*}{ Coefficient } & \multicolumn{2}{|c|}{$95 \% \mathrm{CI}$} \\
\hline & & Lower & Upper \\
\hline Udder drop (cm) & -0.12 & -0.40 & 0.16 \\
\hline Left teat length $(\mathrm{cm})$ & -0.76 & -2.12 & 0.60 \\
\hline Left teat width $(\mathrm{cm})$ & -0.70 & -2.95 & 1.56 \\
\hline Right teat length (cm) & -0.35 & -1.68 & 0.98 \\
\hline Right teat width (cm) & 0.29 & -1.49 & 2.08 \\
\hline Lamb had suspected orf & 5.19 & 2.17 & 8.22 \\
\hline Breed North Country mule vs. Suffolk mule & -1.60 & -3.11 & 0.09 \\
\hline BCS before lambing $\leq 2$ & Reference & & \\
\hline 2.5 & -0.19 & -2.83 & 2.44 \\
\hline 3 & 0.20 & -2.46 & 2.86 \\
\hline$\geq 3.5$ & 1.93 & -0.88 & 4.74 \\
\hline$\overline{B C S}$ at examination $\leq 1.5$ & Reference & & \\
\hline 2 & 3.06 & 0.55 & 5.56 \\
\hline 2.5 & 1.90 & -0.63 & 4.44 \\
\hline 3 & 5.47 & 2.96 & 7.99 \\
\hline$\geq 3.5$ & 2.56 & -0.12 & 5.24 \\
\hline \multicolumn{4}{|l|}{ Ūdder separation score } \\
\hline 1 (minimum separation) & -1.75 & -6.38 & 2.87 \\
\hline 2 & -3.07 & -7.71 & 1.56 \\
\hline 3 & -1.08 & -5.79 & 3.63 \\
\hline 4 & Reference & & \\
\hline 5 & 1.91 & -3.63 & 7.44 \\
\hline 6 & -0.89 & -6.59 & 4.81 \\
\hline 7 & -1.85 & -9.12 & 5.43 \\
\hline 8 to 9 (maximum separation) & \multicolumn{3}{|c|}{ No observations } \\
\hline \multicolumn{4}{|l|}{ Udder drop score } \\
\hline 1 (maximum drop) to 5 & Reference & & \\
\hline 6 & 0.18 & -1.74 & 2.10 \\
\hline 7 to 9 (minimum drop) & -0.09 & -2.03 & 1.86 \\
\hline \multicolumn{4}{|l|}{ Teat placement score } \\
\hline 1 (most medial) to 3 & -0.01 & -2.06 & 2.04 \\
\hline 4 to 6 & Reference & & \\
\hline 7 to 9 (most lateral) & 0.41 & -1.48 & 2.30 \\
\hline Udder contaminated at examination & -0.85 & -3.10 & 1.41 \\
\hline Udder contaminated at previous examination & 1.43 & -0.79 & 3.64 \\
\hline Wool on udder & -0.85 & -2.65 & 0.96 \\
\hline \multicolumn{4}{|l|}{ Bedding at lambing } \\
\hline Clean & Reference & & \\
\hline Moderately dirty & 1.49 & -0.35 & 3.32 \\
\hline Very dirty & -0.54 & -2.32 & 1.23 \\
\hline \multicolumn{4}{|l|}{ Water availability at lambing } \\
\hline Unrestricted & Reference & & \\
\hline Restricted & -0.39 & -2.15 & 1.36 \\
\hline No water available & 0.89 & -1.14 & 2.92 \\
\hline Teat lesion on either teat at examination & 2.95 & 1.89 & 4.00 \\
\hline Traumatic teat lesion on either teat at examination & 1.92 & 0.73 & 3.11 \\
\hline Nontraumatic teat lesion on either teat at previous examination & 3.45 & 2.03 & 4.87 \\
\hline Teat lesion on either teat at previous examination & 3.25 & 2.13 & 4.37 \\
\hline
\end{tabular}

in the final multivariable model is presented in Table 5. Higher udder half SCC was associated with more pendulous udders $(9.6 \%$ increase in $\mathrm{SCC} / \mathrm{cm}$ of drop) and greater total cross-sectional area of the teats $(7.2 \%$ increase in SCC $/ \mathrm{cm}^{2}$; Table 6). Lower SCC were associated with heavier mean litter weight $(6.7 \%$ decrease in $\mathrm{SCC} / \mathrm{kg}$; Table 6). Linear, quadratic, and cubic terms for days in lactation were also significant. The model fit was good (data not shown). Several significant correla- tions were found between variables in the 2 multivariable models (Table 7 ).

\section{DISCUSSION}

This is the first longitudinal study to investigate udder and teat conformation and their effects on lamb weight and SCC in suckler ewes. A combination of linear scores and measurement in centimeters was used 
Table 4. Mixed effects model of factors associated with lamb weight of 101 lambs born to 67 ewes on 1 farm

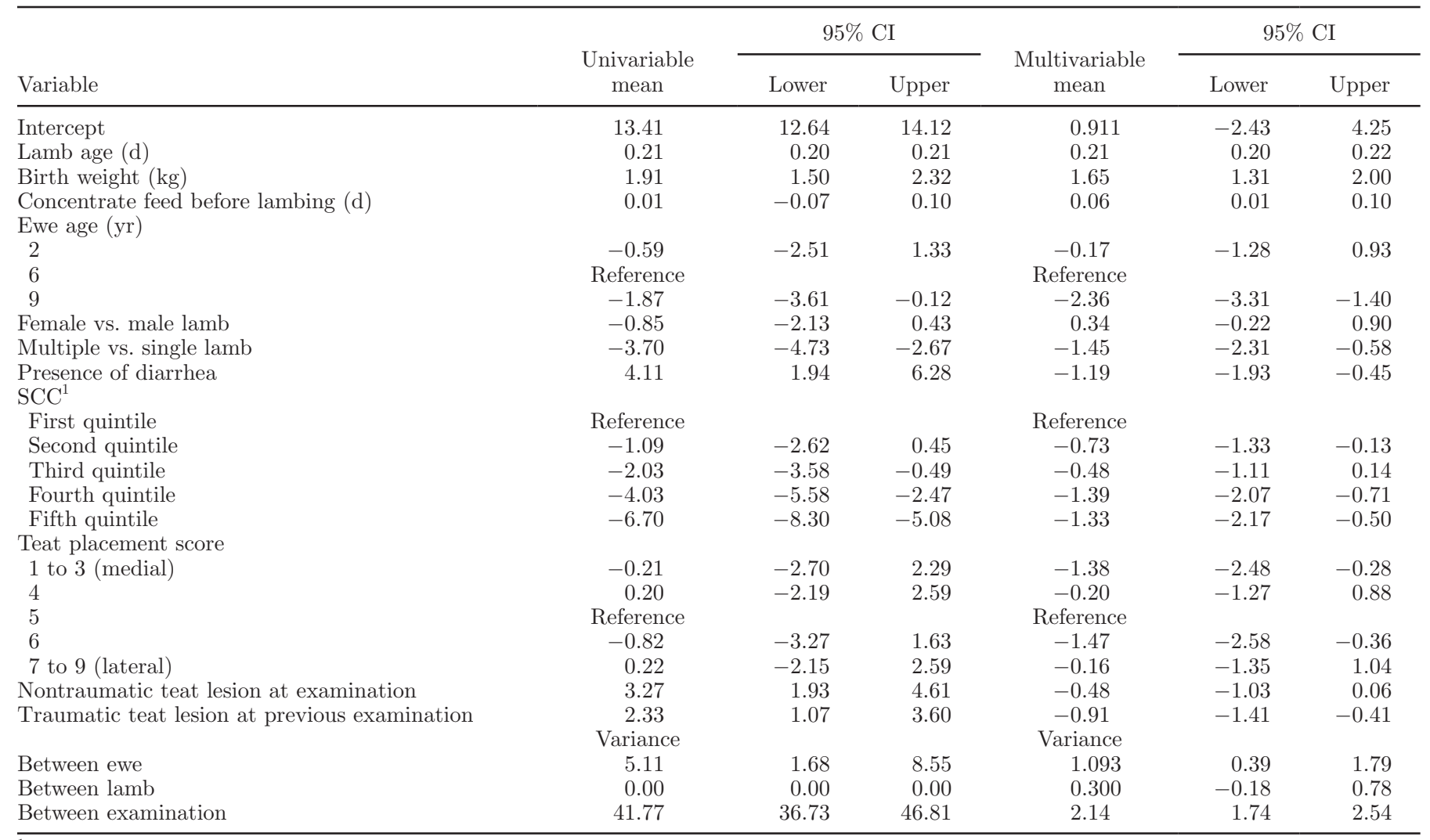

${ }^{1}$ Somatic cell count: $-2 \times \log$-likelihood $=1,219.233$ (312 out of 592 cases used).

to evaluate udder and teat conformation. Similar approaches have been used to assess udder conformation in dairy ewes (de la Fuente et al., 1996; Casu et al., 2006, 2010). Casu et al. (2006) reported that the system developed to score dairy ewe udder conformation had high levels of repeatability across lactations and, assuming that this is so for suckler ewes, then the associations in the current study should affect lamb weight and SCC rather than be a result of these variables.

Suckler ewes are with their lambs $24 \mathrm{~h}$ per day and it is not possible to measure milk yield directly. We have assumed that lamb weight is primarily dependent on ewe milk production after adjustment for known confounders, such as litter size and birth weight, particularly in young lambs with no rumen and no other source of food. Other authors have also used lamb weight as a proxy for milk production and linked this to clinical and subclinical mastitis (Larsgard and Vaabenoe, 1993; Moroni et al., 2007; Arsenault et al., 2008).

Because of the low number of observations of teat placement in the current study in the most medial and most lateral categories of the 9-point scale, categories were merged into 5 classes of approximately equal number of observations. Ewes with a teat placement of score
5 (Figure 1) reared significantly heavier lambs than ewes with more medial or more lateral teat positions. This suggests that this is an optimum teat position that allows the lamb to suckle. Other teat positions were also associated with a higher propensity for teat lesions (Cooper, 2011).

Traumatic teat lesions were associated with a lower lamb weight in the following $14 \mathrm{~d}$. This is most likely because a fresh teat lesion such as a bite would result in a ewe preventing her lamb(s) from suckling until the wound had healed. The lower lamb weight and increased risk of teat lesions in ewes with poor teat position might indicate that lambs were not able to latch on to the teat efficiently or that milk delivery from the teat was impeded when the teat position was too lateral or too medial (Figure 1) so lambs took in less milk when suckling. No other udder conformation variables were associated with lamb weight.

Teat lesions of either type were not significantly associated with a change in udder half SCC (Table 6). This was also reported by Watkins et al. (1991) and might indicate that teat lesions do not increase the risk of bacterial invasion of the udder. In contrast, pendulous udders were associated with an increase in SCC. 
Table 5. Variables associated with the common logarithm $\left(\log _{10}\right)$ of SCC $(\mathrm{n}=568)$ but not included in the multivariable model

\begin{tabular}{|c|c|c|c|}
\hline \multirow[b]{2}{*}{ Variable } & \multirow[b]{2}{*}{ Mean SCC } & \multicolumn{2}{|c|}{$95 \%$ CI } \\
\hline & & Lower & Upper \\
\hline Width of base of udder $(\mathrm{cm})$ & 0.02 & -0.01 & 0.05 \\
\hline North of England mule vs. Suffolk mule as reference ${ }^{1}$ & 0.27 & 0.09 & 0.44 \\
\hline Multiple vs. single lamb & 0.07 & -0.11 & 0.25 \\
\hline Diarrhea in at least 1 lamb $^{1}$ & -0.17 & -0.32 & -0.02 \\
\hline Suspected orf in at least 1 lamb & -0.18 & -0.38 & 0.03 \\
\hline At least 1 lamb thin & -0.01 & -0.18 & 0.17 \\
\hline \multicolumn{4}{|l|}{ Udder separation score $^{1}$} \\
\hline 1 (minimum separation) & Reference & & \\
\hline 2 & -0.15 & -0.37 & 0.08 \\
\hline 3 & -0.06 & -0.31 & 0.18 \\
\hline 4 to 9 (maximum separation) & -0.37 & -0.67 & -0.08 \\
\hline \multicolumn{4}{|l|}{ Udder drop score } \\
\hline 1 (maximum drop) to 5 & Reference & & \\
\hline 6 & -0.23 & -0.44 & -0.01 \\
\hline 7 to 9 (minimum drop) & -0.32 & -0.54 & -0.11 \\
\hline \multicolumn{4}{|l|}{ BCS before lambing $^{1}$} \\
\hline 2 or less & Reference & & \\
\hline 2.5 & -0.37 & -0.67 & -0.07 \\
\hline 3 & -0.41 & -0.71 & -0.11 \\
\hline 3.5 or more & -0.52 & -0.83 & -0.20 \\
\hline \multicolumn{4}{|l|}{ BCS at examination ${ }^{1}$} \\
\hline 1.5 or less & Reference & & \\
\hline 2 & -0.16 & -0.39 & 0.08 \\
\hline 2.5 & -0.27 & -0.51 & -0.03 \\
\hline 3 & -0.43 & -0.68 & -0.19 \\
\hline 3.5 or more & -0.37 & -0.62 & -0.11 \\
\hline \multicolumn{4}{|l|}{ Teat placement score } \\
\hline 1 (most medial) to 3 & 0.08 & -0.16 & 0.33 \\
\hline 4 to 6 & Reference & & \\
\hline 7 to 9 (most lateral) & 0.25 & 0.02 & 0.49 \\
\hline Traumatic teat lesion at examination ${ }^{1}$ & -0.14 & -0.25 & -0.02 \\
\hline Traumatic teat lesion at previous examination & -0.04 & -0.15 & 0.07 \\
\hline Nontraumatic teat lesion at examination ${ }^{1}$ & -0.14 & -0.29 & -0.00 \\
\hline Nontraumatic teat lesion at previous examination ${ }^{1}$ & 0.11 & -0.03 & 0.26 \\
\hline Lesion near teat orifice at previous examination & -0.07 & -0.15 & 0.01 \\
\hline Udder contaminated at examination & -0.11 & -0.25 & 0.03 \\
\hline Udder contaminated at previous examination & -0.08 & -0.21 & 0.06 \\
\hline Woolly udder (yes vs. no) & 0.01 & -0.23 & 0.24 \\
\hline Bedding at lambing & Coefficient & & \\
\hline Clean & Reference & & \\
\hline Moderately dirty & 0.11 & -0.10 & 0.33 \\
\hline Very dirty & 0.13 & -0.09 & 0.35 \\
\hline \multicolumn{4}{|l|}{ Water at lambing } \\
\hline Unrestricted & Reference & & \\
\hline Restricted & -0.02 & -0.24 & 0.20 \\
\hline No water available & -0.02 & -0.26 & 0.23 \\
\hline
\end{tabular}

${ }^{1}$ These variables were also lagged by one observation.

Casu et al. (2010) reported that dairy ewes with pendulous udders also had a higher SCC. It may be that pendulous udders are more exposed to environmental contamination, thus increasing challenge with environmental pathogens and an associated increase in SCC. In addition, in the current study, total cross-sectional area of the teats was positively associated with SCC. This may be because a bigger teat cistern may facilitate a greater volume of residual milk in the teat in which pathogens may multiply or because such teats have less patent teat sphincters, which would increase the risk of bacterial entry into the teat canal.

A study over 7 yr from one university in the United States (Paape et al., 2007) reported that composite SCC from dairy cows and dairy goats, but not dairy ewes, increased with parity. They also reported, as in the current study, that SCC decreased in the second month of lactation, probably due to the dilution effect of increased milk yield, and then rose again. In contrast to Paape et al. (2007), Lafi (2006) reported that 
Table 6. Multivariable model of the common logarithm $\left(\log _{10}\right)$ of SCC of udder halves of 67 ewes from 1 farm $^{1}$

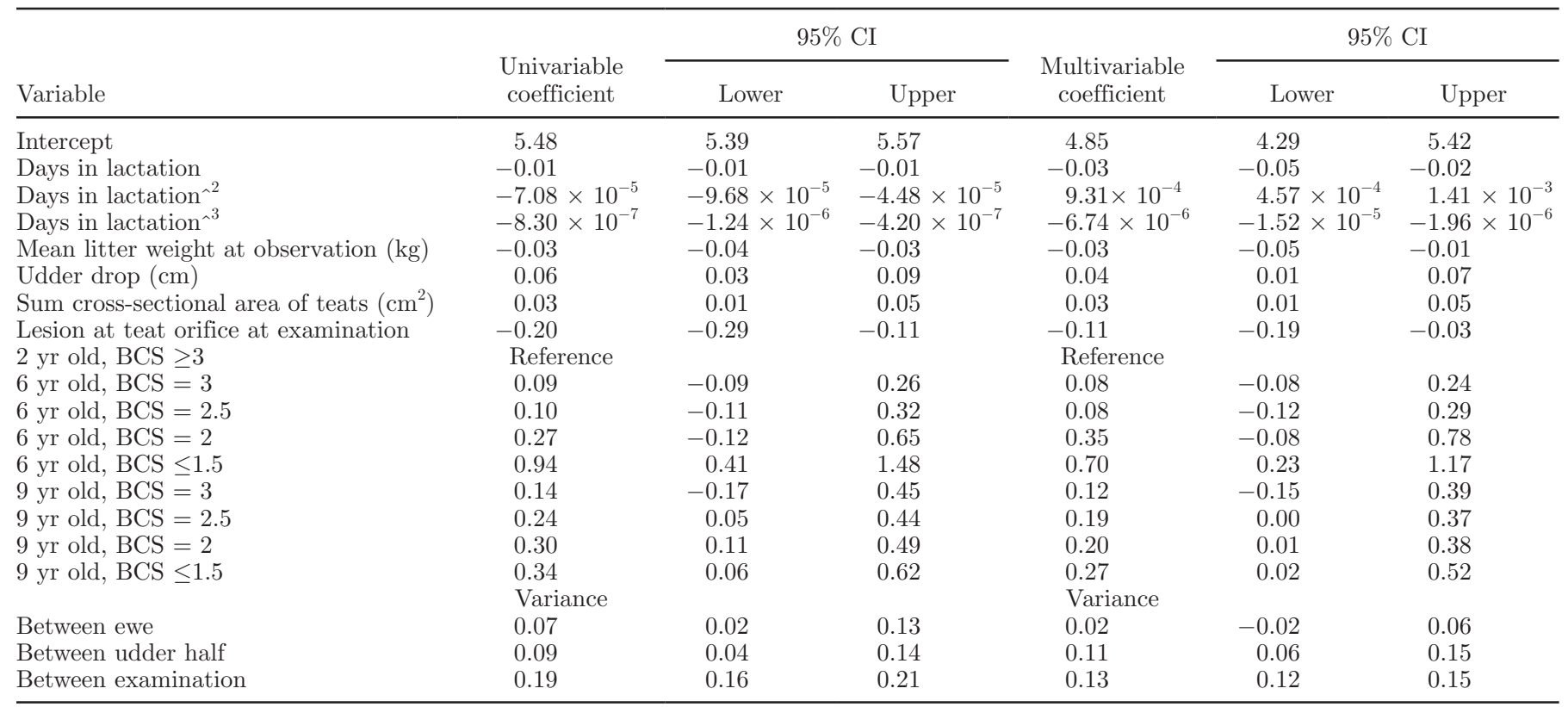

${ }^{1} 2 \times \log$-likelihood $=646.116$ (539 out of 568 cases).

multiparous ewes had a significantly higher SCC than primiparous ewes in a study of 46 dairy Awassi flocks. Watkins et al. (1991) reported that the prevalence of subclinical mastitis increased with age in suckler ewes in a longitudinal study of subclinical mastitis in 358 ewes from 7 flocks in the United Kingdom. It is probable that older ewes have been exposed to more pathogens over the course of numerous lactations, which might explain the higher SCC in older ewes in the current study.
The BCS and age of ewe were significantly correlated $(\mathrm{r}=0.62$; Table 7$)$; thus, the association between ewe BCS and lamb weight independent of ewe age was difficult to assess in the current study. A significant effect of age of ewe on lamb weight was observed, with lambs reared by 9 -yr-old ewes weighing, on average, $2.36 \mathrm{~kg}$ less than lambs reared by 6-yr-old ewes. Al-Sabbagh et al. (1995) reported a lower total weaning weight of lambs reared by 7 -yr-old ewes compared with 4 -yr-old

Table 7. Correlations $(\mathrm{r}>0.5)$ of explanatory variables in multivariable models

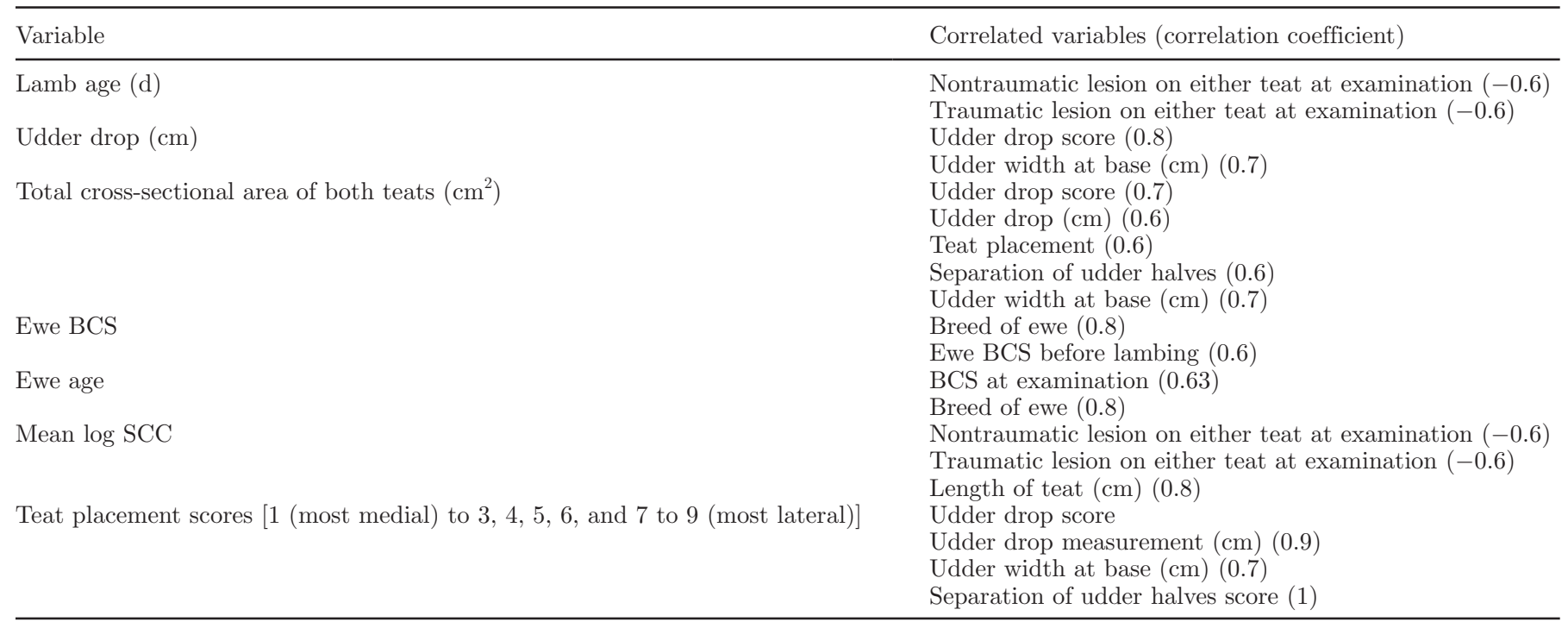



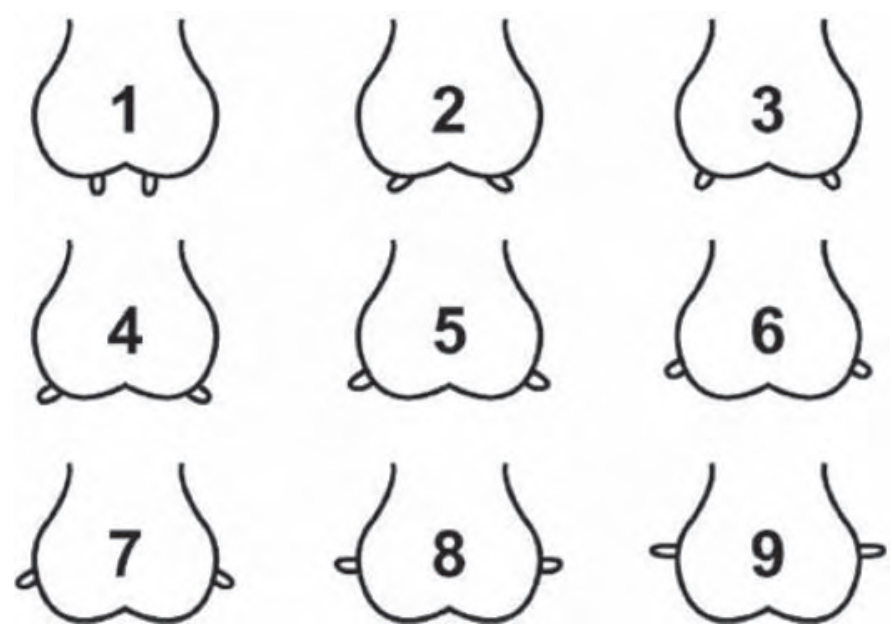

Figure 1. Teat placement scores: 1 (most medial) to 9 (most lateral; source, Casu et al., 2006).

ewes, despite a higher total birth weight of lambs in ewes of $7 \mathrm{yr}$. As subclinical IMI has been associated with decreased milk production (Saratsis et al., 1999; Gonzalo et al., 2002), it may be that milk production or perhaps milk quality is more likely to be suboptimal in old ewes. Lamb weight was marginally (10\% significance) lower for primiparous ewes than for 6-yrold ewes in the current study. It could be argued that middle-aged ewes may be under less metabolic strain because younger ewes are still growing themselves.

Although the current study was small, the detail is useful and can inform future investigations and programs considering selection of ewes. Lamb production may be improved by management choices used by the sheep farmer. For example, removing older ewes from the flock would leave a younger flock more able to rear lambs from milk and grass. Providing sufficient feed to ewes to optimize body condition during gestation and maximize milk production during lactation would reduce the risks from poor BCS on lamb growth and ewe SCC. Supplementary feed to lambs reared by older ewes would increase lamb growth rate and reduce demand on the ewe. In the future, it might be possible to improve udder shape and teat position through genetic selection of suckler ewes.

\section{CONCLUSIONS}

This study is the first to report the effect of poor udder and teat conformation on the growth of lambs and subclinical infection in suckler ewes. Associations between high SCC and poor udder and teat conformation were observed, indicating that ewes with poor udder conformation were more likely to have high SCC.
Lamb growth weight was lower when ewes had high SCC, indicating lower milk production from such ewes, possibly because of damage to the mammary parenchyma from bacterial infection. Lamb growth rate was also lower when teat conformation was poor, possibly indicating that these lambs could not feed efficiently from ewes with poor conformation or that teat conformation affected milk production. We conclude that hidden production losses from subclinical IMI and poor udder shape exist in this flock of ewes that, if generalizable, is a considerable hidden cost to farmers producing prime lamb.

\section{ACKNOWLEDGMENTS}

This project and S. Huntley studentship were supported by EBLEX (Kenilworth, Warwickshire, UK), the levy body for beef and sheep farmers. S. Cooper was self funded. We thank the farmer for access to his sheep and Ed Smith for help with data collection.

\section{REFERENCES}

Albenzio, M., L. Taibi, A. Muscio, and A. Sevi. 2002. Prevalence and etiology of subclinical mastitis in intensively managed flocks and related changes in the yield and quality of ewe milk. Small Rumin. Res. 43:219-226.

Al-Sabbagh, T. A., L. V. Swanson, and J. M. Thompson. 1995. The effect of ewe body condition at lambing on colostral immunoglobulin G concentration and lamb performance. J. Anim. Sci. 73:2860-2864.

Arsenault, J., P. Dubreuil, R. Higgins, and D. Bélanger. 2008. Risk factors and impacts of clinical and subclinical mastitis in commercial suckler-producing sheep flocks in Quebec, Canada. Prev. Vet. Med. 87:373-393.

Casu, S., I. Pernazza, and A. Carta. 2006. Feasibility of a linear scoring method of udder morphology for the selection scheme of Sardinian sheep. J. Dairy Sci. 89:2200-2209.

Casu, S., S. Sechi, S. L. Salaris, and A. Carta. 2010. Phenotypic and genetic relationships between udder morphology and udder health in dairy ewes. Small Rumin. Res. 88:77-83.

Cooper, S. 2011. A study of ovine udder abnormalities: Identifying the risk factors for teat lesions. MS Thesis. University of Warwick, Coventry, UK

de la Fuente, L. F., G. Fernandez, and F. San Primitivo. 1996. A linear evaluation system for udder traits of dairy ewes. Livest. Prod. Sci. 45:171-178.

Fthenakis, G. C., and J. E. T. Jones. 1990. The effect of sub-clinically induced mastitis on milk yield of ewes and on the growth of lambs. Br. Vet. J. 146:43-49.

Gonzalo, C., A. Ariznabarreta, A. J. Carriedo, and F. San Primitivo. 2002. Mammary pathogens and their relationship to somatic cell count and milk yield losses in dairy ewes. J. Dairy Sci. 85:14601467.

ISO (International Organization for Standardization). 2008. Quality management systems-Requirements. ISO 9001:2008. ISO, Geneva, Switzerland.

Keisler, D. H., M. L. Andrews, and R. J. Moffatt. 1992. Subclinical mastitis in ewes and its effect on lamb performance. J. Anim. Sci. 70:1677-1681.

Lafi, S. Q. 2006. Use of somatic cell counts and California Mastitis Test results from udder halves milk samples to detect subclini- 
cal intramammary infection in Awassi sheep. Small Rumin. Res. $62: 83-86$.

Larsgard, A. G., and A. Vaabenoe. 1993. Genetic and environmental causes of variation in mastitis in sheep. Small Rumin. Res. 12:339-347.

Marie-Etancelin, C., J. M. Astruc, D. Porte, H. Larroque, and C. Robert-Granié. 2005. Multiple-trait genetic parameters and genetic evaluation of udder-type traits in Lacaune dairy ewes. Livest. Prod. Sci. 97:211-218.

Moroni, P., G. Pisoni, G. Varisco, and P. Boettcher. 2007. Effect of intramammary infection in Bergamasca suckler sheep on milk parameters and lamb growth. J. Dairy Res. 74:340-344.

Paape, M. J., G. R. Wiggans, D. D. Bannerman, D. L. Thomas, A. H Sanders, A. Contreras, P. Moroni, and R. H. Miller. 2007. Monitor- ing goat and sheep milk somatic cell counts. Small Rumin. Res. $68: 114-125$

Rasbash, J., C. Charlton, W. J. Browne, M. Healy, and B. Cameron. 2009. MLwiN Version 2.1. Centre for Multilevel Modelling, University of Bristol, UK

Saratsis, P., C. Alexopoulos, A. Tzora, and G. C. Fthenakis. 1999. The effect of experimentally induced subclinical mastitis on the milk yield of dairy ewes. Small Rumin. Res. 32:205-209.

Seykora, A. J., and B. T. McDaniel. 1985. Udder and teat morphology related to mastitis resistance: A review. J. Dairy Sci. 68:20872093.

Watkins, G. H., A. R. Burriel, and J. E. T. Jones. 1991. A field investigation of subclinical mastitis in sheep in southern England. Br. Vet. J. 147:413-420. 